\title{
Interspace/Undercanopy Foraging Patterns of Beef Cattle in Sagebrush Habitats
}

\author{
Kevin A. France, ${ }^{1}$ Dave C. Ganskopp, ${ }^{2}$ and Chad S. Boyd ${ }^{2}$
}

Authors are ${ }^{1}$ Provincial Rangeland Ecologist, Sustainable Resource Development, Lands Division, Calgary, Alberta, Canada; and ${ }^{2}$ Rangeland Scientists, USDA Agricultural Research Service, Eastern Oregon Agricultural Research Center (EOARC), 67826-A, Hwy 205, Burns, OR 97720, USA.

\begin{abstract}
Forage selection patterns of cattle in sagebrush (Artemisia L.) communities are influenced by a variety of environmental and plant-associated factors. The relative preference of cattle for interspace versus under-sagebrush canopy bunchgrasses has not been documented. Potential preferences may indirectly affect habitat for sage-grouse and other ground-nesting birds. Our objectives were to investigate grazing patterns of cattle with respect to undercanopy (shrub) and interspace tussocks, determine the influence of cattle grazing on screening cover, and relate shrub morphology to undercanopy grazing occurrence. Eighteenday replicated trials were conducted in the summers of 2003 and 2004. Findings suggest cattle initially concentrate grazing on tussocks between shrubs, and begin foraging on tussocks beneath shrubs as interspace plants are depleted. Grazing of undercanopy grass tussocks was negligible at light-to-moderate utilization levels $(<40 \%$ by weight). Grass tussocks under spreading, umbrella-shaped shrub canopies were less likely $(P<0.001)$ to be grazed than those beneath erect, narrow canopies. Horizontal screening cover decreased $(P<0.001)$ with pasture utilization. At the trial's end, removal of $75 \%$ of the herbaceous standing crop induced about a $5 \%$ decrease in screening cover in all strata from ground level to $1 \mathrm{~m}$ with no differences among strata $(P=0.531)$. This implied that shrubs constituted the majority of screening vegetation. Our data suggest that conservative forage use, approaching $40 \%$ by weight, will affect a majority (about $70 \%$ ) of interspace tussocks and a lesser proportion (about $15 \%$ ) of potential nest-screening tussocks beneath sagebrush. Probability of grazing of tussocks beneath shrubs, however, is also affected by shrub morphology. These findings will help managers design grazing programs in locales where habitat for ground nesting birds is a concern.
\end{abstract}

\section{Resumen}

El patrón de selección del forraje del ganado en comunidades arbustivas de Artemisia L. tiene influencia de unos factores asociados a la planta y otros ambientales. La preferencia relativa del ganado por gramíneas en inter espacios de arbustivas comparado con aquellos que se localizan debajo de los arbustos no ha sido documentada. La preferencia potencial puede afectar indirectamente el hábitat del urogallo y otras aves que anidan en la superficie del suelo. Los objetivos de este estudio fueron investigar los patrones de pastoreo del ganado con respecto a manchones de gramíneas que se localizan debajo de los arbustos y el espacio entre ellos. También se determinó la influencia del pastoreo del ganado sobre la cubertura vegetal relacionando la morfología del arbusto con la ocurrencia del pastoreo debajo del mismo. Se hicieron ensayos repetidos de 18 días en el verano de 2003 y 2004. Los resultados sugieren que el ganado se concentra inicialmente en el pasto entre los arbustos y comienza a pastorear debajo de los mismos en la medida que se agotan las plantas entre los espacios. La cantidad de macollos debajo de los arbustos fue insignificante con niveles de utilización ligera y moderada $(<40 \%$ por peso). Los macollos, debajo de arbustos con forma de sombrilla, fueron menos susceptibles $(P<0.001)$ de pastorear que aquellos localizados debajo de arbustos erguidos y estrechos. La cubertura horizontal disminuyó $(P<0.001)$ con la utilización del pasto. Al finalizar el estudio, la remoción del $75 \%$ de la producción forrajera indujo una disminución del $5 \%$ de la cobertura vegetal en todos los estratos desde el nivel del suelo hasta $1 \mathrm{~m}$, aunque no se detectaron diferencias entre estratos $(P=0.531)$. Esto implicó que los arbustos constituyeron la mayoría de vegetación estudiada. Nuestros datos sugieren que el uso conservador del forraje, cerca del $40 \%$, en base a peso, afecta la mayoría (cerca de $70 \%$ ) de los manchones y en menor proporción (cerca de $15 \%$ ) de los manchones potenciales para anidar debajo del arbusto. La probabilidad de pastoreo de manchones de zacates debajo de los arbustos se afecta por la morfología del arbusto. Estos resultados son de utilidad para el diseño de programas de manejo del pastoreo a nivel local donde existe la preocupación por el hábitat para aves que anidan en la superficie del suelo.

Key Words: bunchgrass, forage selection, grazing behavior, ground nesting birds, sage-grouse

The Eastern Oregon Agricultural Research Center is jointly operated by the USDA-ARS and the Oregon State University Agricultural Experiment Station.

Proprietary or trade names are for information only, and do not convey endorsement of one product over another.

At time of research, France was a Graduate Research Assistant, Dept of Rangeland Ecology and Management, Oregon State University, Corvallis, OR, USA.

Correspondence: Dave Ganskopp, USDA-ARS, Eastern Oregon Agricultural Research Center, 67826-A Hwy 205, Burns, OR 97720, USA. Email: david.ganskopp@oregonstate.edu

Manuscript received 18 May 2006; manuscript accepted 13 April 2008.

\section{INTRODUCTION}

Caespitose grasses in the northern Great Basin occur in interspaces and beneath canopies of sagebrush (Artemisia L.) with no reported spatial trend or pattern. In these communities, forage selection by cattle is affected by plant availability and bunchgrass structure (Ganskopp et al. 1992; Ganskopp and Rose 1992), and at larger scales, geospatial characteristics like slope, aspect, topography, and distance from water affect 
livestock distribution and forage selection (Gillen et al. 1984; Senft et al. 1985; Owens et al. 1991; Pinchak et al. 1991; Bailey et al. 1996; Kie and Boroski 1996). Interspace versus undercanopy foraging patterns of cattle, however, have not been studied.

Livestock grazing has the potential to affect habitat for a variety of ground-nesting birds (Crawford et al. 2004; Walsberg 2005). Cattle grazing in particular has been indirectly implicated as a causative factor in the decline of greater sagegrouse (Centrocercus urophasianus; Schroeder et al. 2004) in the western United States and southern Canada, primarily due to reduced screening cover in nesting habitat (Gregg 1992; Gregg et al. 1994; Sveum et al. 1998). Sage-grouse and other sagebrush-associated species such as sage thrasher (Oreoscoptes eoscoptes montanus; Reynolds and Rich 1978), and lark sparrow (Chondestes grammacus; Walcheck 1970) often nest beneath sagebrush with near-nest herbage providing screening cover. Given the recent interest in the well being of many sagebrush-steppe avians, there is a need to quantify the selective grazing patterns of cattle at the individual plant scale.

The objectives of this study were 1) to quantify cattle selection of interspace and undercanopy grasses, 2) to assess the influence of sagebrush morphology on the likelihood of undercanopy grazing by cattle, and 3) to quantify the effects of cattle grazing on screening cover at potential nest sites beneath shrubs. We hypothesized that 1) forage selection would be affected by interspace/undercanopy location, 2) shrub morphology would affect likelihood of undercanopy grazing, and 3) visual obstruction would decrease in near-ground strata but not higher strata as forage utilization progressed.

\section{MATERIALS AND METHODS}

\section{Study Site}

We established four 6.1-6.5-ha pastures within a Wyoming big sagebrush (Artemisia tridentata Nutt. subsp. wyomingensis Beetle and Young)/bottlebrush squirreltail (Sitantion hystix [Nutt.] J. G. Sm.) community on Bureau of Land Management property $100 \mathrm{~km}$ south of Burns, Oregon (lat $42.98^{\circ} \mathrm{N}$, long $\left.119.25^{\circ} \mathrm{W}\right)$. Elevation was approximately $1525 \mathrm{~m}$ with mean annual precipitation of $26.8 \mathrm{~cm}$ (Anderson et al. 1998). The locale has historically been grazed by cattle in the growing season and is also documented sage-grouse nesting habitat (Willis et al. 1993). In each pasture, five 50-m line transects, spaced at 20-m intervals, were used to measure shrub canopy cover (Canfield 1941). Gaps in live sagebrush cover $>10 \mathrm{~cm}$ were excluded from measures. Sagebrush density was obtained by counting the number of plants rooted within a $2 \times 50 \mathrm{~m}$ belt transect centered over each of the 50-m transects. Herbaceous canopy cover was estimated, by species, within $2540 \times 50 \mathrm{~cm}$ quadrats spaced at $1-\mathrm{m}$ intervals along each transect. Canopy cover and density values were averaged across transects and pastures to characterize site vegetation.

\section{Project Design}

The study was repeated in 2003 and 2004, with grazing commencing on 7 and 20 July, respectively. Both trials began at the end of the herbaceous growing season. Project design was a randomized complete block $(n=4)$ evaluating the relative use by cattle of interspace and undercanopy grasses. Thirty randomly generated UTM coordinates were derived for each of the four pastures. Coordinates were then located in the field with a GPS unit, and the nearest suitable $(>40 \mathrm{~cm}$ tall) sagebrush plant chosen. The $40-\mathrm{cm}$ dimension was used because Connelly et al. (2000) suggest sage-grouse typically nest beneath relatively large sagebrush. Shrub dimensions recorded included maximum height, maximum diameter, and the widest diameter perpendicular to the first to facilitate derivation of elliptical crown area and crown volume (elliptical crown area $\times$ height). We also measured an "angle of accessibility" to characterize access to undercanopy tussocks for grazing. The bottom of a meter stick was placed against the edge of the marked tussock at a point closest to the canopy drip line and the outside end of the stick lifted until it made contact with sagebrush foliage or twigs. We then measured a) the ground distance from the point of canopy interception to the base of the grass plant, and b) the distance vertically from shrub canopy contact point to the ground, and used these measures to derive angle of accessibility. We marked one randomly chosen perennial tussock beneath the drip line of each sagebrush (undercanopy), and then marked the closest tussock of the same species in the adjacent unshielded interspace. Tussock positions were georeferenced to facilitate subsequent relocation. After livestock turnout, grass plants were checked for evidence of grazing every second day.

Four yearling heifers (approx. $325 \mathrm{~kg}$ ) were stocked in each pasture for $18 \mathrm{~d}$ in 2003 ( 7 July-25 July), and three heifers for $18 \mathrm{~d}$ in 2004 (20 July-6 August). In each pasture, $201-\mathrm{m}^{2}$ plots were clipped before grazing began and subsequently at 7,14 , and $18 \mathrm{~d}$. The initial clipping estimated standing crop to help establish stocking rate, and subsequent data were used to quantify herbage utilization as the study progressed. Harvested materials were oven dried at $50^{\circ} \mathrm{C}$ for a minimum of $48 \mathrm{~h}$ before weighing.

In 2004, we used a modified Robel pole (Robel et al. 1970) to estimate visual obstruction near each georeferenced sagebrush plant. The 2.54-cm-diameter pole was $1 \mathrm{~m}$ long, and marked in alternating fluorescent pink and white $2.54-\mathrm{cm}$ bands ( 39 bands total). For data analysis, strata were established by combining three sequential bands (e.g., bands $1-3=$ strata 1). Visual obstruction was evaluated by scoring bands within strata as visible or not visible. Obstruction for each strata was then derived by averaging the band scores across locations within a pasture and sampling date. The pole fit over a rebar stake driven into the ground at the base of each sagebrush to assure consistent repositioning across sampling dates. The sighting azimuth was from permanently marked (rebar) points in the interspace $2 \mathrm{~m}$ from the pole. Measurements were sighted from a height of $50 \mathrm{~cm}$, which approximates eye level of a coyote. Visual obstruction measures were obtained before turnout, repeated at weekly intervals, and at trial's end.

\section{Data Analyses}

Herbage Utilization. Linear regression was used to quantify rates of herbage utilization separately for each year. Percent utilization (by weight) served as the dependent variable and the number of days cattle had occupied pastures was the independent variable. 
Table 1. Vegetation composition for study sites used in 2003-2004 in southeast Oregon to evaluate interspace/undercanopy forage selection by cattle grazing in sagebrush/bunchgrass vegetation.

\begin{tabular}{lcc}
\hline \multicolumn{1}{c}{ Component } & $\begin{array}{c}\text { \% canopy cover } \\
{[\bar{x}(\text { SE) }]}\end{array}$ & $\begin{array}{c}\text { Density (plants } \cdot \text { ha }^{-1} \text { ) } \\
{[\bar{x}(\text { SE) }]}\end{array}$ \\
\hline Wyoming big sagebrush & $17.1(0.30)$ & $3209.0(36.60)$ \\
All shrubs & $19.3(0.76)$ & $4666.7(76.50)$ \\
Perennial grasses & $5.5(3.66)$ & $430.6(46.10)$ \\
Annual grasses & $0.1(0.01)$ & $37.4(0.95)$ \\
Perennial forbs & $3.4(0.05)$ & $121.5(0.89)$ \\
Annual forbs & $0.3(0.01)$ & $82.4(0.49)$ \\
\hline
\end{tabular}

Plant Position Effects on Grazing. Data were examined for skewness and kurtosis (PROC UNIVARIATE; SAS 1999) with no transformations required. The response variable was the percent of plants grazed within a block. Data were analyzed with the use of a repeated-measures analysis of variance (PROC MIXED; Littell et al. 1996) with $2 \mathrm{yr}$, four blocks (pastures), two treatments (undercanopy or interspace), and nine measurement days as a repeated factor. Covariance structure was "autoregressive order one," as determined with the use of the Akaike's Information Criterion (Littell et al. 1996).

Shrub Morphology Effects on Undercanopy Grazing. The relationship between shrub morphology and probability of grazing of undercanopy grasses was examined with the use of logistic regression (SAS 1999). Data for both years were pooled in the analysis and individual shrubs and associated grass tussocks were considered experimental units. End-of-trial grazing scores $(0=$ ungrazed, $1=$ grazed $)$ of undercanopy grasses were related to shrub height, elliptical crown area, volume, angle of accessibility, and year of data collection.

Visual Obstruction. Data for visual obstruction were analyzed with the use of repeated-measures analysis of variance (PROC MIXED; Littell et al. 1996) with four blocks (pastures), 13 treatments (visual obstruction strata), and four sampling days as a repeated factor with an "autoregressive order one" covariance structure. Values following " \pm " symbols are standard errors of the mean (SE) in all instances.

\section{RESULTS}

The dominant shrub across pastures was Wyoming big sagebrush (Table 1) with lesser amounts of low sagebrush (Artemisia arbuscula Nutt.), and green rabbit-brush (Chrysothamnus viscidiflorus Pallas ex Pursh). Perennial grasses included the dominant bottlebrush squirreltail, and subordinates Thurbers needlegrass (Stipa thurberiana Piper), bluebunch wheatgrass (Psendoroegneria spicata [Pursh] A. Love), and Sandberg's bluegrass (Poa secunda J. Presl). Prominent perennial forbs included low pussytoes (Antennaria diamorpha [Nutt.] Torr. \& Gray), largeflower hawksbeard (Crepis occidentalis Nutt.), velvet lupine (Lupinus leucophyllus Dougle. ex Lindl.), and longleaf phlox (Phlox longifolia Nutt.). Annual forbs included maiden blue-eyed Mary (Collinsia parviflora Lindl.), western tansymustard (Descurainia pinnata [Walt.] Britt.), and fireweed (Epilobium spp. L.). Cheatgrass (Bromus tectorum L.) was the only annual grass detected.

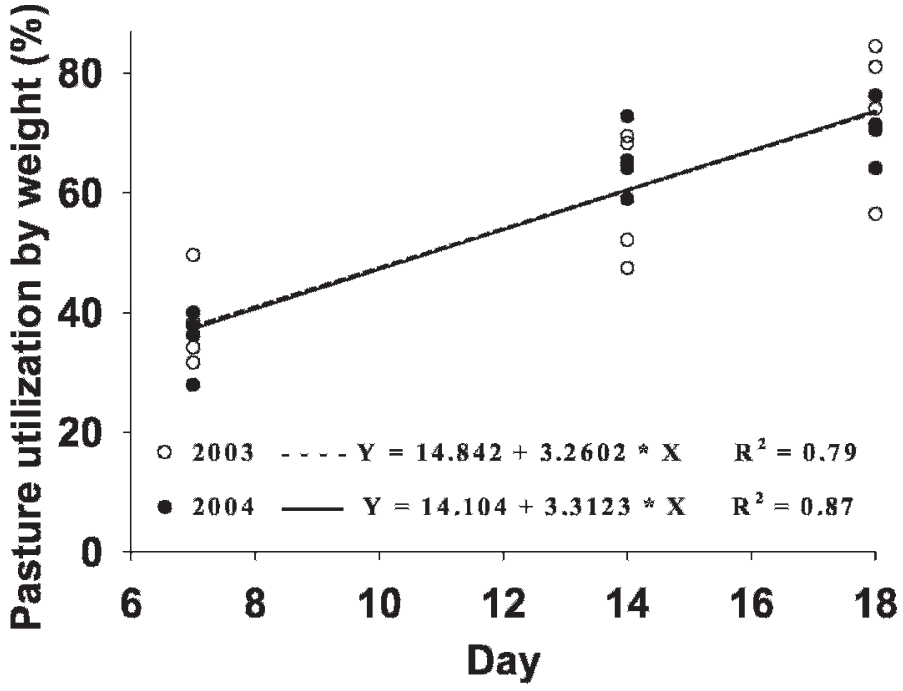

Figure 1. Regression lines and data depicting percent forage utilization by weight among four pastures and elapsed days of cattle grazing at Foster Flat, Oregon in 2003 and 2004 in 18-d trials assessing forageremoval patterns beneath and between sagebrush.

In 2003, calendar year precipitation was $24.8 \mathrm{~cm}$ (93\% of the 40-yr average; National Oceanic and Atmospheric Administration [NOAA] 2003) and initial standing crop was $182 \mathrm{~kg} \cdot \mathrm{ha}^{-1} \pm 2.76$. In 2004 , precipitation for the calendar year was $17.2 \mathrm{~cm}$ (64\% of the 40-yr average; NOAA 2004) and pregrazing standing crop was $103 \mathrm{~kg} \cdot \mathrm{ha}^{-1} \pm 1.77$.

Forage utilization advanced linearly across time (linear regression model $P<0.001$ for 2003 and 2004). Best-fit lines were essentially superimposed (Fig. 1), suggesting our varied stocking rates accomplished near-uniform rates of herbage utilization across years. In 2003, mean forage utilization was $77 \% \pm 1.8$ (by weight) at trial's end and all interspace and $70 \% \pm 1.2$ of undercanopy grass plants were grazed (Fig. 2). In 2004 , mean forage utilization was $71 \% \pm 1.1$ (by weight) at the

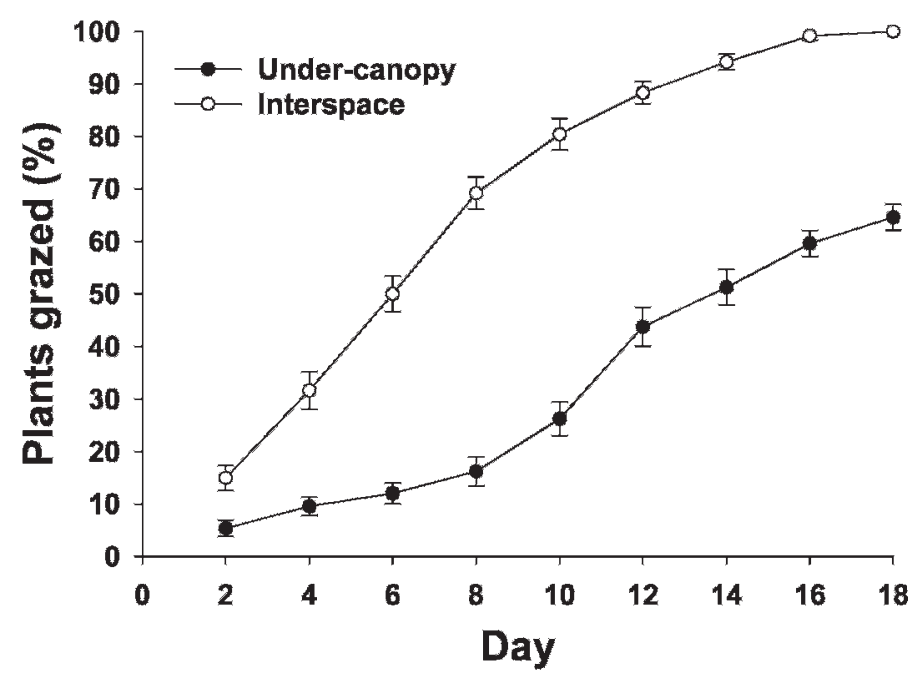

Figure 2. Percent of interspace and undercanopy grass tussocks grazed as cattle progressively utilized herbage in a study documenting forage-selection patterns in sagebrush/steppe vegetation near Foster Flat, Oregon in 2003 and 2004 (displayed data combined across years). 


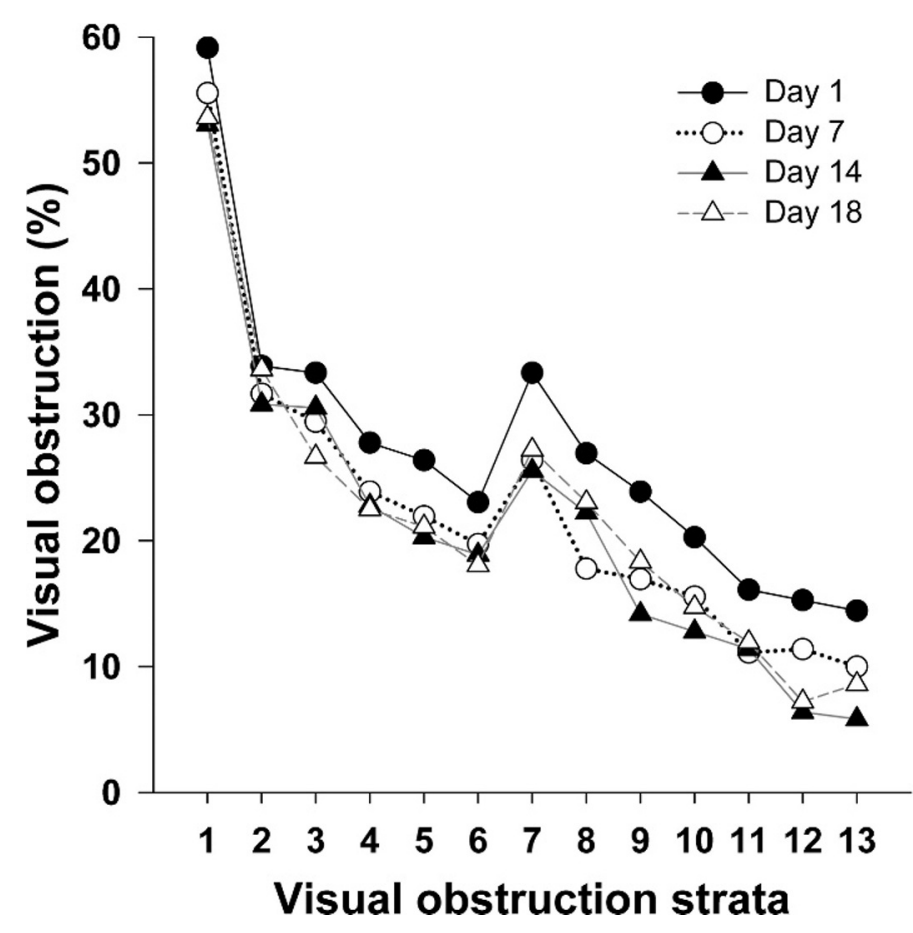

Figure 3. Percent horizontal visual obstruction for four sampling dates across 13 strata of a Robel pole at Foster Flat, Oregon in 2004 as cattle grazed in an 18-d trial assessing forage-removal patterns beneath and between sagebrush. Increasing strata values reflect increasing elevation from ground level in $7.6-\mathrm{cm}$ increments.

end of the trial and $100 \%$ of the interspace and $62.5 \% \pm 0.2$ of the undercanopy tussocks were grazed (Fig. 2). Analyses of percent of interspace and undercanopy plants grazed across time exhibited significant location $(P<0.001)$ and day $(P<0.001)$ effects, and a location $\times$ day interaction $(P<0.001)$. The significant location $\times$ day interaction implies use of interspace and undercanopy tussocks by cattle was not similar across the trial. Year effects and other interactions were not significant $(P \geq 0.22)$, so data were pooled across years for presentation (Fig. 2).

The likelihood of grazing undercanopy plants was positively related to angle of accessibility $(P<0.001, \beta=0.046 \pm 0.011)$ and results were similar between years $(P=0.312)$. No other shrub morphology variable contributed to the likelihood of undercanopy grazing $(P>0.05)$. The mean angle of accessibility for shrubs was $68.5^{\circ} \pm 0.3$. Classification table output indicated the logistic regression model correctly classified plants as grazed or not grazed about $65 \%$ of the time.

Significant visual obstruction effects included strata and trial day $(P<0.001)$. As trial day advanced (in concert with increasing pasture utilization), an anticipated interaction with strata did not occur $(P=0.531)$, implying all strata were affected equally over time (Fig. 3).

\section{DISCUSSION}

Prior to this study, livestock forage selection patterns had not been evaluated relative to interspace/undercanopy tussock positioning in any biome. Thus we had no preconceived notions regarding the relative rates of use between locales or evidence of potential thresholds where cattle may shift their attentions from one locale to another. The distinct separation, relative positions, and shapes of lines for plotted location $\times$ day means (Fig. 2) suggest interspace tussocks were initially defoliated at a relatively constant and more rapid rate than undercanopy tussocks over the first $8 \mathrm{~d}$ of our trials. Simply put, cattle initially grazed most heavily upon interspace grasses.

At about Day 8, when $70 \%$ of interspace tussocks had been grazed, an upward shift in slope of the undercanopy line (Fig. 2) implied undercanopy tussocks were subsequently used at a more rapid rate than over prior days. A corresponding reduction in rate of change for the interspace line after Day 8 suggests rate of use simultaneously declined slightly for the more rarely encountered ungrazed interspace plants over the remaining days. Both patterns support speculation that grazing attention shifted toward understory tussocks near Day 8 when overall herbage use was about $41 \%$ (Fig. 1) among pastures.

Depending on sampling procedures, our observed disparities in use of interspace/understory tussocks may also confound rangeland assessment findings. If stubble height measures are used to monitor grazing and adjust management, our data emphasize a need for measuring a random selection of pasture plants that includes both undercanopy and interspace tussocks. Measures based solely on more easily viewed interspace plants would likely overestimate herbage utilization and underestimate stubble height compared to assessments of randomly selected tussocks from both locales.

As to visual obstruction by vegetation, sagebrush constituted the majority of screening for the upper-level strata, which ranged from $10 \%$ to $20 \%$ visual obstruction. Although we anticipated a decrease in obstruction values in the lower strata as herbage utilization increased, magnitude of change in visual obstruction was similar across all strata. The absence of a strata $\times$ day interaction may be wholly or partially explained by 1 ) ephemeral leaf fall from sagebrush and removal of the herbaceous component may have coincided; or 2) the physical and foraging activities of cattle affected all strata equally; or perhaps some combination of both of these factors. However, the fact that we removed $75 \%$ of the herbaceous standing crop and affected only a $5 \%$ decline in lower-level obstruction suggests sagebrush constituted the bulk of the intervening vegetation. That the bulk of screening cover at potential nest sites was provided by sagebrush is somewhat contradictory to other reports that emphasized the role of herbaceous plants as visual barriers (Connelly et al. 1991; Delong et al. 1995; Sveum et al. 1998). The relative importance of sagebrush and associated herbage could differ on more productive sites if the herbaceous component makes up a greater proportion of the screening cover.

\section{MANAGEMENT IMPLICATIONS}

We found cattle use of undercanopy tussocks was minimal until standing crop utilization reached about $40 \%$. This suggests management that restricts herbage utilization to $\leq 40 \%$ could be used to help sustain screening cover for nesting birds beneath sagebrush. This utilization level will likely vary depending on sagebrush density, sagebrush arrangement (e.g., 
patchy vs. uniform distribution), bunchgrass structure, and accompanying forage production levels.

Additionally, sagebrush morphology affects the probability of grazing for individual tussocks beneath shrubs. Tussocks beneath broad, umbrellalike canopies (with a low angle of accessibility) were less likely to be grazed than those associated with taller and more columnlike canopies. Thus, cattle impacts on nesting habitat may be affected by site factors, like sagebrush shape and stature, that are not readily controlled with grazing management.

If stubble height measures are used to monitor grazing management, initial preferences of cattle for interspace tussocks underscores a need for measuring a random selection of grasses that includes both undercanopy and interspace tussocks. Measurements based solely on interspace plants would likely overestimate herbage utilization and underestimate overall stubble height compared to randomly selected tussocks.

That the bulk of screening cover at potential nest sites was provided by sagebrush is somewhat contradictory to other reports that put more emphasis on the role of herbaceous plants as visual barriers. Our study sites were at the arid end of the sagegrouse nesting spectrum, and the relative importance of sagebrush as a source of screening cover may be lessened on more mesic areas with increased potential for herbaceous production. These findings will help managers minimize potentially deleterious grazing affects on critical avian nesting habitat.

\section{LITERATURE CITED}

Anderson, E. W., M. M. Borman, and W. C. Krueger. 1998. The ecological provinces of Oregon. Corvallis, OR: Oregon Agricultural Experiment Station. Special report 990. $138 \mathrm{p}$.

Balley, D. W., J. E. Gross, E. A. Laca, L. R. Rittenhouse, M. B. Coughenour, D. M. Swift, And P. L. Sims. 1996. Mechanisms that result in large herbivore grazing distribution patterns. Journal of Range Management 49:386-400.

Canfield, R. H. 1941. Application of the line intercept method in sampling range vegetation. Journal of Forestry 39:388-394.

Connelly, J. W., M. A. Schroeder, A. R. Sands, and C. E. Braun. 2000. Guidelines for management of sage-grouse populations and habitat. Wildlife Society Bulletin 28:967-985.

Connelly, J. W., W. L. Wakkinen, A. P. Apa, and K. P. Reese. 1991. Sage grouse use of nest sites in southeastern Idaho. Journal of Wildlife Management 55:521-524.

Crawford, J. A., R. A. Olson, N. E. West, J. C. Mosley, M. A. Schroeder, T. D. Whitson, R. F. Miller, M. A. GregG, And C. S. Boyd. 2004. Ecology and management of sage-grouse and sage-grouse habitat. Journal of Range Management 57: $2-19$.

Delong, A. K., J. A. Crawford, and D. C. Delong, JR. 1995. Relationships between vegetational structure and predation of artificial sage grouse nests. Journal of Wildlife Management 59:88-92.
Ganskopp, D. G., R. Angell, and J. Rose. 1992. Response of cattle to cured reproductive stems in a caespitose grass. Journal of Range Management 45:401-404.

Ganskopp, D. G., AND J. Rose. 1992. Bunchgrass basal area affects selection of plants by cattle. Journal of Range Management 45:538-541.

Gillen, R. L., W. L. Krueger, and R. F. Miller. 1984. Cattle distribution on mountain rangeland in northeastern Oregon. Journal of Range Management 37:549-553.

GregG, M. A. 1992. Habitat use and selection of nesting habitat by sage-grouse in Oregon [thesis]. Corvallis, OR, USA: Oregon State University. $42 \mathrm{p}$.

Gregg, M. A., J. A. Crawford, M. S. Drut, and A. K. Delong. 1994. Vegetational cover and predation of sage grouse nests in Oregon. Journal of Wildlife Management 58:162-166.

KIE, J. B., AND B. B. Boroski. 1996. Cattle distribution habitats and diets in the Sierra Nevada's of California. Journal of Range Management 49:482-488.

Littell, R. C., G. A. Milliken, W. W. Stroup, and R. D. Wolfinger. 1996. SAS system for mixed models. Cary, NC, USA: SAS Institute.

[NOAA] National Oceanic and Atmospheric Administration. 2003. Climatological data: annual summary, Oregon 109:1-36.

[NOAA] National Oceanic and Atmospheric Administration. 2004. Climatological data: annual summary, Oregon 110:1-34.

Owens, M. L., K. L. Launchbaugh, and J. W. Holloway. 1991. Pasture characteristics affecting spatial distribution of utilization by cattle in mixed brush communities. Journal of Range Management 44:118-123.

Pinchak, W. E., M. A. Smith, R. H. Hart, and J. W. Waggoner, JR. 1991. Beef cattle distribution patterns on foothill range. Journal of Range Management 44: 267-275.

Reynolds, T. D., AND T. D. Rich. 1978. Reproductive ecology of the Sage Thrasher (Oreoscoptes montanus) on the Snake River Plain in south-central Idaho. Auk 95:580-582.

Robel, R. J., J. N. Briggs, A. D. Dayton, and L. C. Hulbert. 1970. Relationships between visual obstruction measurements and weight of grassland vegetation. Journal of Range Management 23:295-297.

SAS InSTITUTE INC. 1999. SAS procedures guide, release 8.0. Cary, NC, USA: SAS Institute.

Schroeder, M. A., C. L. Aldridge, A. D. Apa, J. R. Hohne, C. E. Braun, S. D. Bunnell, J. W. Connelly, P. A. Deibert, S. C. Gardner, M. A. Hilliard, G. D. Kobriger, S. M. McAdam, C. W. McCarthy, J. J. McCarthy, D. L. Mitchell, E. V. Rickerson, AND S. J. Stiver. 2004. Distribution of sage-grouse in North America. The Condor 106:363-376.

Senft, R. L., L. R. Rittenhouse, and R. G. Woodmeasee. 1985. Factors influencing patterns of cattle grazing behavior on shortgrass steppe. Journal of Range Management 38:82-95.

Sveum, C. M., D. Edge, and J. A. Crawford. 1998. Nesting habitat selection by sage grouse in south-central Washington. Journal of Range Management 51: 265-269.

WalCheCK, K. C. 1970. Nesting bird ecology of four plant communities in the Missouri River breaks, Montana. Wilson Bulletin 82:370-382.

WALSBERG, G. E. 2005. Cattle grazing in a national forest greatly reduces nesting success in a ground-nesting sparrow. The Condor 107:716-716.

Willis, M. J., G. P. Keister, D. A. Immell, D. M. James, R. M. Powell, and K. P. Durbin. 1993. Sage grouse in Oregon. Portland, OR, USA: Oregon Department of Fish and Wildlife Research Section. Wildlife Research Report 18. 56 p. 